who are charged with the control of the retail trade, and it is based on the fact that the buyer has the right to claim from the seller a free and sufficient warranty of the quality of the bought articles.

I am, Sirs, yours respectfally,

P. F. VAN HAMEL RoOS

Chief Editor of the Revue Internationale des Falsifications.

\section{"AN ACTION FOR FEES AT DUNDEE."} To the Editors of THE LANCEr.

SrRs, - The facts in the above case were not sufficiently stated in your columns to give a clear idea of the dispute. I attended two midwifery cases for Dr. Moon-one of them, acknowledged by letter, thanking me, and stating I would get my share when paid ; the other verbally, though not with the same condition as to payment. After an interval of two years I sent an account rather than the usual delicate letter. This elicited the humiliating statement that the patient, whom he had specially thanked me for attending, was three years in arrears, and the other in the hands of a debt collector. Dr. Moon's ultimatum was, since I would not wait till he was paid, that I was to render an account to the patients. I refused to do this, but was willing to take something on account from him. Why he did not push for payment was none of 'my busiress. Both accounts were recoverable; one of the patients, indeed, had a salary of over $£ 150$ per annum. As regards the code of etiquette, I followed it in every detail. I was offered at the emergency a fee by both parties, but answered that I received remuneration through the family attendant. Before the case went into court Dr. Moon sent one of the patierts to pay me, but I would have nothing to do with his patient. Cases of this kind, when fully reported, as was done in the local papers, are not without value both to the profession and to the public. I am, Sirs, yours truly,

Robert Mrller, M.A., M.B., \&o.

* * We have omitted part of our correspondent's letter, which, we think, introduced fresh matter extraneous to the case.-HD. L.

\section{CERTIFYING UNDER THE LUNACY ACTS, To the Eiditors of THE LANCHT.}

SIRS, - In the leading article in THE LANCET of Oct. 6th on "The Law in relation to the Criminal Responsibility of the Insane" you partially endorse the views of a writer in the Times on this subject who merely states the notorious fact that "certifiably insane" is a phrase which " can only mean that a couple of doctors can be found to certify that in their opinion the man is insane" ; and you appear to agree with him that such evidence may, at any rate, be open to doubt in a plea of irresponsibility on the ground of insanity. But, while the concurrent testimony of two qualified practitioners may thus, when submitted to legal scrutiny, fail in establishing the irresponsibility or responsibility of an accused person, the same testimony-i.e., the signing of two certificates-is asserted by the daily practice of our profession to constitute sufficient grounds for depriving an individual of liberty and confining him in an asylum for a period varying from a month to a lifetime. In other words, the evidence which, in the former case, may be insufficient to secure the release of a morally guiltless person or the conviction of a criminal is in the latter, adequate to confine an innocent person for an indefinite period in an institution which at any rate so far resembles a prison that the individual confined in it ceases to be free. Outside the purely medical question of treatment there is the legal question of interference with liberty; and our profession should rejoice, I think, at any measure which would relieve them of this latter invidious duty. That medical men should hitherto have so cheerfully undertaken so unique and awful a responsibility is not a little wonderful. At present I would merely suggest that the opinions of the two certifying medical men, as stated on the face of the certificates, and the necessity for confinement in an asylum, should, as a matter of routine, be subjected, before the removal of the patient, to revision by legal and medical experts acting on behalf of some properly constituted legal authority. Should this suggestion appear to meet with the approval of any of the readers of THE LANCET I shall be happy, if you will kindly affurd me space, to discuss it at greater length at a future date.

\section{LIVERPOOL}

(From OUR OWN CORRESPONDENT.)

The Medical Institution.

THE first meeting of the fifty-fifth session of the local Medical Institution was held on the 4th inst. Over 160 members and associates were present. Before delivering his address the President, Mr. Channcy Pazey, referred to the serions injury which recently befel one of the members of the institution, Dr. Joseph Wiglesworth, whilst engaged in his duties at Rainhill Asylum, an injury which would have proved fatal but for the prompt and excellent surgical treatment which he recaived at the hands of Mr. Dames Harrisson, assisted by the resident assistant medical officers of the asylum. He felt sure that all present would agree that a message of sympathy and good feeling should be sent to Dr. Wiglesworth at the earliest opportunity ; and also that all would join with him in congratulating Mr. Damer Harrisson on the successful result of his exertions. This gentleman will, Mr. Puzey added, have his reward in the lifelong recollection that he was the means of saving the life oi. his friend and former fellow student whe $n$ it was in the greatest peril. The following resolution was carried unanimously: "The members of the Liverpool Medical Institution desire to take this, the earliest opportunity, of conveying to their fellow member, Dr. Joseph Wiglesworth, the assurance of their sympathy with him in the peril and suffering through which he has recently passed, their hearty congratulations on his recovery, and their earnest hope that he will before long be $a b$ 'e to return to the important dutiss entrusted to him." Mr. Puzey commenced his presidential address with a gracefut tribute to the addresses of his predecessors in the chair, which; he observed, had been of such a high standard as to make it difficult for him to follow them. Fortunately they had left him the advantage of being able to speak on a subject in which he was personaily interested, and as he assumed that the session would be devoted as usual to the consideration of the most recent advances in the practice of the various branches of the medical profession, he thought it well to look back a little and recall some of the events of interes. and of adrance within the last thirty years. In considering what subject he should select, Mr. Puzey thought of tha various improvements in the details of surgical practice which had taken place since he came to Liverpool, and in answer to the question, "What improvement had held its ground longest, and still appeared likely to do so in much the same form as when introduced to notice?" his answer wa. that the "antiseptic animal ligature" beld the firet place. It was just a 4 uarter of a century since it was introduced by Professor Lister, and it was first used on the human subject. and successfully, in the old Royal Infirmary of this city by Mr. Bickersteth. Mr. Puzey then alluded to what took place before this year (1869) with regard to the best mode of controlling arterial hæmorrhage-acupressure $v$ the old fashioned ligature, torsion $r$ acupressure, and, finally, the catgut ligature $v$. torsion. Allusion was next made to the late Sir James Simpson's experiments on animals by compressing the arteries with needles, and to the subsequent history of acupressure as applied to the human subject by Mr, Crompton of Birmingham, IMr. William Adams of the London Hospital, Mr. Bickersteth at the Liverpool Royal Infirmary, Mr. Page of Carlisle, Dr. Greig of Dandee, the late Dr. Pirrie and Dr. Keith of Aberdeen. Mr. Puzey then detailed his own experiences of acupressure and that of the late Mr. Cooper Forster of Guy's Hospital. In seeking for the reasons why acupressure, after achieving such brilliart results, had fallen into disuse, he observed that in scme cases it was by no means easy to apply, and took much time until practice had been acquired. Then, when many reedles were used, it was difficult to accurately close the wound; suppuration occurred not infrequently, and bæmorrbage often cccurred, necessitating ligature of the vessels. The subject of torsion was next dealt with and the soluble wire ligature, and finally the "antiseptis animal ligature," which, applied to an artery, virtually su: rounded it with a ring of living tissue, which actually strengthened the vessel where it cbstructed it. This was dealt with at length, Mr. Pazey remarking that he had some idea of giving his address the title of "A Surgical Revival," For, as be observed, the Listerian ligature is the ontcome of the revival of an idea so old that it is wellnigh impossible to say when it was new; and, as he truly remarked, it was impossible for any who commenced surgical work during 